\title{
American biofutures: ideology and utopia in the Fukuyama/Stock debate
}

\section{R E Ashcroft}

Francis Fukuyama, in his Our Posthuman Future, and Gregory Stock, in his Redesigning Humans, present competing versions of the biomedical future of human beings, and debate the merits of more or less stringent regimes of regulation for biomedical innovation. In this article, these positions are shown to depend on a shared discourse of market liberalism, which limits both the range of ends for such innovation discussed by the authors, and the scope of their policy analyses and proposals. A proper evaluation of the human significance and policy imperatives for biomedical innovation needs to be both more utopian in its imagination, and more sophisticated in its political economy. In essence, the Fukuyama/Stock debate tells us more about current US political ideology than it does about the morality of human genetic and biopsychological engineering.

Correspondence to: Dr R E Ashcroft, Imperial College of Science, Technology and Medicine, Department of Primary Health Care and General Practice, ICSTM Charing Cross Campus, Reynolds Building, St Dunstan's Road, London W6 8RP UK; r.ashcroft@ic.ac.uk' n his Illuminations, in his Theses on the philosophy of history, the German Jewish philosopher and modernist mystic Walter Benjamin draws the reader's attention to a drawing by Paul Klee. ${ }^{1}$ The drawing is of the Angel of History. Benjamin points out that this angel is being blown forward by the wind of history while facing backwards. Thus, the angel's interpretation of what is happening is only ever an account of what has happened; and the angel's speculations about what is to come are shaped by the perceived regularities and contingencies of the past, and by the prospect that the wind will continue to bear him or her aloft and onward.

This is a troubling image in at least two ways. First, the usual sense we have that we may have some control over at least the immediate future is denied; our agency, our power to make things happen, does not appear to figure in this image. The familiar idea we have that we can know the past, but not the future, is wrenched free of its accompanying thought, that the unpredictability of the future has to do not with the problem of induction (according to which the future would be predictable if only our knowledge of the laws of nature and the "initial conditions" which could completely specify the world's state at a particular moment), but with our human power of intentional change. In this sense, the image denies the Marxist postulate, that "man makes history, but not under conditions of his own choosing". Second, the image is of an angel. On at least some theological accounts, angels lack the capacity for free choice that is the human burden and blessing, they nevertheless are powerful, redemptive figures, agents of God's transformation of the world. Yet this angel seems to be moving too fast to transform anything, still less redeem anything. To restore the redemptive power to this angel, we could assume that it redeems the past through its gaze over the expanding field of the past, by taking it in as a whole (rather than as, say, a ruptured field of ruins, failures, and lost causes) - thus the angel of history is actually Hegel's owl of Minerva.

When philosophy paints its grey in grey, a shape of life has become old, and it cannot be rejuvenated, but only recognized, by the grey in grey of philosophy; the owl of Minerva begins its flight only with the onset of dusk. ${ }^{2}$

That is, we can only grasp what is happening when it is almost over, and when it is too late to change it (or to understand it). (The Owl is the symbolic animal of Minerva, the Roman goddess of wisdom, corresponding to the Greek goddess Athena). Alternatively, we could assume that the angel, far from being the subject of the wind, is actually the wind itself. On this assumption, the redemption is the process of historical change; every moment of that change is redeemed in virtue of being part of that process, and faith demands recognition that redemption is achieved through that process. But it is precisely faith, because the end of redemption is unknowable; the wings of the angel shield it from our gaze.

Francis Fukuyama, noted historiological pundit and advisor to presidents, and Gregory Stock, director of the medicine, technology, and society programme at University of California Los Angeles, have been debating biotechnological futures across Europe and the United States for some months now, promoting their new books, Our Posthuman Future and Redesigning Humans respectively. ${ }^{3-7}$ They recently "performed" at a meeting in London, courtesy of the radical think tank, the Institute of Ideas, with support from the Wellcome Trust, Novartis, and Prospect magazine. This meeting had been energetically promoted in the press and other media, and the tickets sold out weeks in advance. In the event more the 950 people attended this debate, which was chaired by a very well known journalist, Jonathan Dimbleby, and featured commentaries from Professor Robin Lovell-Badge, one of the leading British animal stem cell researchers, Professor Raanan Gillon (formerly editor of the Journal of 
Medical Ethics), and Brian Appleyard, journalist and science commentator. All the contributions were fluent and engaging, and the debate was wide ranging. ${ }^{8}$

The theme of the debate was the potential for new biomedical technologies radically to transform human existence, the probable social consequences of such transformation, and the moral evaluation of the possible worlds implied and of the steps we might take towards them. Fukuyama's position was that while new biomedical technologies, (he devoted particular attention to psychopharmacological manipulation of mood, techniques for extending human life span, and germline genetic engineering), offered great potential for relieving suffering, they posed major risks. The risks described fell into two broad categories: a challenge to the very idea of a common human nature which would found human dignity and human rights, and a threat to political economic stability with potential for promoting violent conflict. If we change the genetic and psychological constitution of humans significantly, we risk destroying the idea of human unity, undermining the ideal of personal autonomy, and erasing the basis of moral equality. In addition, by extending the life span of those able to afford such technologies we pose various dangers: intergenerational struggles, and geopolitical imbalance between the aging, rich "North" and the young, poor "South". Fukuyama acknowledges that to some extent these problems already exist; his prediction is that things will get worse. His solution is improved national and international regulation, to focus efforts on technologies which will permit treatment of illness, while barring applications which would weaken or breach human rights or respect for human dignity. Not coincidentally, Fukuyama is a member of the recently established United States President's Council on Bioethics. ${ }^{9}$ Stock, on the other hand, presents a vision of unlimited human improvement in the free market, with decidedly sceptical views on the power of national or international regulation to control innovation. He rejects the treatment/enhancement distinction appealed to by Fukuyama, and locates human nature in our capacity to choose, take risks, and improve on our natural endowments, rather than in those endowments themselves. While Fukuyama warns that this approach to human biomedical transformation is essentially Nietzschean, Stock sees this as no warning at all, but in fact a commendation.

Stock and Fukuyama share a vision in which the power of technology to change human history, and humanity itself, is so enormous that it can be moderated, at best, but not ultimately resisted. A striking thing about the Stock/ Fukuyama debate is the limited range of futures described. If biomedicine is so powerful, it is because it acts upon so many different types of material and capacity. If we permit our utopian imaginations free rein, then surely it would be possible to summon up a perhaps unlimited range of possible futures: as yet undreamed of human capacities and forms of sociability and social organisation. Thus, the shape of the future is fixed not by technical possibility or some necessary trajectory determined by the past, but by concrete social choices and struggles over the forms of technical innovation and access to them. Hence the basis of the Stock/Fukuyama technological determinism is not in the technology, but in human nature. They argue that the direction the technology will take is controlled by some fairly basic human impulses: to improve one's welfare and to ensure a better future for one's children. In gloomier moments, they admit a third impulse: to dominate others. Hence both Fukuyama and Stock hold a relatively low opinion of the value of government intervention and control; at its best it can act as a brake and the medium of social control over the most vicious instincts of would be exploiters of others; at its worst, it is the medium through which the exploiters can most efficiently exploit and dominate the weak and the dissident. Thus they overlook the positive contribution that government could make to equalising the balance of social power, promoting social solidarity globally and locally, and encouraging research and investment into improving collective welfare and the welfare of the weakest and most vulnerable. Yet both Stock and Fukuyama subscribe to the mainstream view in US politics, which is that there are limits on the capacity of the state to improve human welfare; limits which are set by human, biological, and psychological nature. ${ }^{10}$ The irony of Stock's position is particularly acute here; his attitude to social engineering implies a commitment to the view that human biology can be utterly transformed, but not our desires and interests. Fukuyama fears these desires and interests: they will selfishly shape our technologies and the uses to which they are put, while at the same time undermining their basis in biological and psychological human nature. The vision he portrays of the Stockian future is one in which we are hopelessly adrift, without even a common humanity to bind us.

Stock and Fukuyama share a good deal, then, in their vision of political society, and in their unquestioned commitment to the free market, subject to "appropriate" regulation. They differ in the style and extent of regulation they propose, but they share a common discourse of economic and quasieconomic interests as the drivers of technological, social, and species change. They further naturalise these interests as essential constituents of "human nature". This is most apparent in the second element of their common discourse: the set of ends to which new biomedical technologies will be put. Both Stock and Fukuyama, as good liberals, do not believe that it is the role of the state to prescribe the Good at which its citizens should aim. Moreover, they allow that citizens will often be committed to diverse and plural versions of the Good, and that these versions may compete or conflict, such that the state's preferential commitment to some or other version of the Good could be seen as tyrannical or illegitimate. They do allow that a commitment to certain basic liberal values of liberty, equality before the law, and due process is essential for individual and social flourishing, and hence that liberal, market democracy may impose certain constraints on its members. And in the light of this commitment, both Stock and Fukuyama hold that it is better that the new biomedical technologies be developed in liberal democracies than elsewhere-in countries which do not share "our" values. The classical liberal problem of whether we can separate formal and substantive accounts of the Good is never far away from their debates. In particular, Fukuyama often seems to invoke a substantive account of the Good closely associated with a metaphysical account of human rights. None the less, while publicly eschewing the idea that a substantive commitment to the Good can be made by the state or society at large, it is curious that both Stock and Fukuyama share an account of the kinds of goods which citizens will in fact pursue. The standard list of biomedical possibilities is: longer life; reduced suffering from endogenous diseases such as cancer, diabetes, and heart disease; removal or amelioration of degenerative diseases (especially those affecting consciousness and decision making capacity); increased intelligence, and increased physical beauty. In addition to these goals, there is a common ground for decision making in selection of methods to achieve these goals or trading off between goals: individual choice (presumably moderated by morality and human decency). Because of the tight linkage posited between individual choice, instrumental rationality, and moral agency, Stock is sanguine about sex selection technologies, on the basis that people will in fact use this technology "responsibly". Where they choose irresponsibly, societal pressure, over time, will tend to reinstate numerical parity between the sexes. Fukuyama, in contrast, points to the "negative externalities" for collective welfare that could ensue from unregulated personal choice. But these externalities are theorised as pathological, and exceptional, market failure, rather than an indication that the market discourse is inappropriate in this field. Hence, the idiom of consumer 
choice remains the dominant idiom for both. Moreover, the kind of goals that Fukuyama and Stock posit as the likely ends of consumer choice in the biomedical supermarket are goals that are in some sense instrumental, and they are drawn from a limited set of the possible goals of human improvement.

The goals posited are instrumental, in that none of them are ends in themselves; intelligence or a long life are not as such valuable, although they can be enjoyed in their own right on occasion. Rather, they permit the enjoyment of more fundamental goals, such as pleasure; or, in Kantian vein, they permit agency. In the moral order where substantive goals are hidden, or unshared, the only standard for improvement (and improvement is the ideal pointed to by both Stock and Fukuyama) is relative improvement over some other state, as judged by the participants in the evaluation. It is no accident that sporting prowess is so often invoked in the enhancement debate, since athletic excellence is arguably meaningless in itself, but it does exist in a field with definite rules and measurable standards, as defined by the participants in that field. It is also an image of, and training ground for, competition in other walks of life, principally, the marketplace. Hence the suspicion hangs over the Fukuyama/Stock debate that all the enhancement debate is really about is setting fair rules for market competition; and, as John Harris and others have repeatedly said, if you allow private education, why not allow genetic enhancements which promote intelligence. ${ }^{11}{ }^{12}$ This suggests a thoroughly socialised image of the genome, in which social capital is built into one's genome by one's parents. Take another example: concentration on holding back degenerative disease while at the same time extending life is on its own terms a perfectly coherent and morally worthwhile thing to attempt. Yet ideologically it binds together two very late capitalist obsessions: extending one's opportunities to acquire "utility" (presumably through consumption) and extending one's capacity to be an effective actor in the (labour) marketplace (by holding off physical and mental decay) $\cdot{ }^{13}$ In terms of political economy, then, framing the reproductive and vital game this way has the (perhaps unintended) consequence of expanding the supply side of the labour market, reducing the risk of pay off in pensions and life assurance markets, and expanding the demand side of the consumer goods markets, as well as extending the range of those markets (more and better "health care products").

Lest this critique appear too far fetched, let me note some of the possible capacities for enhancement that are not discussed by Fukuyama and Stock. Firstly, consider capacities for human relationships and understanding. We hear nothing about enhancing the capacity for love, empathy, understanding, tolerance, or benevolence. This is so in spite of the rigorous physicalism of both of their accounts of human nature, which would imply that if humans are benevolent, tolerant, and so on, there must be a physical, and hence manipulable, basis for this. Secondly, consider capacities for resisting infectious disease. Stock does discuss this briefly in his discussion of artificial chromosomes, but this discussion occupies only three of the 277 pages of his book. ${ }^{14}$ This is a curious lack of emphasis, not least because one of the few genetic facts we all know is that being heterozygous for the sickle cell gene protects the carrier against malaria. Some people also appear to have an inherited resistance to the form of the HIV virus prevalent in Africa. Now, being charitable, it is probable that Stock and Fukuyama include resistance to infectious disease in the broad class of resistance to disease and physical degeneration generally. None the less, most of their discussion focused on reduction of risks of endogenous diseases (diabetes, heart disease, cancer, and so on). These are the principal killers of the citizens of the United States and Western Europe (apart from motor vehicle accidents and gunshot wounds, which do not appear to have a genetic basis), mainly because they strike "late in life" and are to some extent related to dietary and lifestyle factors, rather than to classic public health risk factors (hygiene, food and water supply, living conditions). These are also the foci of the growing research and development initiatives around "polygenic disorders". Apart from the intrinsic interest and importance of these diseases, there is the obvious pay off that return on investment should be heavy. Interestingly, Fukuyama concentrates his worries on the possibility that these technologies of life span expansion will actually work, with disastrous consequences (he thinks) for political stability and for the financial structure of the economy. Yet, he does have his finger on the right pulse, in that this is the only point in his argument where he acknowledges the problems of the poor three quarters of the world. The ends that are not factored into the enhancement debate, save in the brief discussion of artificial chromosomes in Stock's book, are precisely those which could make the greatest difference in the medium term, namely, those which could combat infectious disease (such as HIV/AIDS, tuberculosis, malaria, sleeping sickness, and so on).

In defence of Stock and Fukuyama, it could be objected that making an enhancement technology available to promote resistance to infectious disease would be wholly unfeasiblehow is germline gene therapy to be made available to say three billion people of reproductive age, free or at marginal cost price? Genetic modifications are quintessential individual "medicines", in that they must be tailored to the individual and delivered under highly controlled clinical conditions; they are not likely to be like pills which can be dispensed in bulk and at (relatively) low manufacturing cost. If this is the case, we can raise the question of whether, firstly, the cash poor will seek shorter cuts to the advantages the cash rich can pay for (old style negative eugenics); whether, secondly, major public investment in technologies which can only benefit a tiny minority of the already advantaged is just; and thirdly, whether the appropriate focus of regulation is not on biomedicine as such and the morality of individual use, but on research and development investment in technologies of marginal benefit in assuaging common human misery. ${ }^{15}$

What would the Angel of History tell us about this? I think he or she would draw out three morals from this story. First, that the wind of technological change may be hard to resist, but it is possible to navigate using it, rather than simply being blown hither and fro willy nilly. Hence it is not a question of utopia or dystopia, but which utopia, dystopia, or mixture we chart a course for. ${ }^{16}{ }^{17}$ The fatal confusion of Stock and Fukuyama's accounts of liberty and value in market liberalism gives us little hope that so called opinion leaders have fully fashioned opinions of their own. Hence it behoves us to do better. In fairness to Stock and Fukuyama, both have sketched powerful and intelligent, albeit fractured and warped accounts of our biomedical futures. But, and this is the Angel's second observation, the materials they have used to construct their visions from are those ready to hand in their own political corner of the world, and represent no advance on that political vision, but merely a restatement thereof. Like most political utopias, these bioethical images of the future tell us more about present ideological commitments than about future possibilities. $^{18}$ Thirdly, then, the Angel reminds us that however unpromising the materials, we are challenged to redeem them in hope: and that hope should be for a better future, not merely an intensified present. Thus, the critique of biomedicine cannot be either made from the market liberalism which continues to leave so much misery in its wake, nor from a cautious, quietist, regulatory state craft. Risks should be taken, and we should launch ourselves in the future energetically; yet to do so we need to set aside the self serving and incoherent ideology which currently frames bioethical debate. Indeed, the signal merit of Fukuyama and Stock's exchanges is to make us aware (or to remind us) that this ideological frame is there. 


\section{ACKNOWLEDGEMENT}

The author thanks Dr Piers Benn for his encouragement.

The work here presented is based on the author's attendance at the Posthuman Futures debate, organised by the Institute of Ideas and Prospect magazine, held at the Institute of Education, London, 2002. The author attended on behalf of the Journal of Medical Ethics, with a complimentary ticket supplied by the Institute of Ideas.

\section{REFERENCES}

1 Benjamin W. Illuminations. New York: Schocken Books, 1969: 257-8.

2 Hegel GWF. Elements of the philosophy of right. Cambridge:

Cambridge University Press, 1991: 23.

3 Fukuyama F. Our posthuman future: consequences of the biotechnology revolution. London: Profile Books, 2002.

4 Stock G. Redesigning humans: choosing our children's genes. London: Profile Books, 2002. The US edition published by Houghton Mifflin has a different subtitle: our inevitable genetic future.

5 Fukuyama F, Stock G. Biotechnology: our slippery slope? Prospect 2000;75: 16-20.

6 http://www.sais-ihu.edu/faculty/fukuyama/

7 http://research.mednet.ucla.edu/pmts/Stock.htm
8 Institute of Ideas. A posthuman future? From the end of history to the end of human nature. Examining the social and political implications of human genetics [transcript of the debate]. London: Institute of Ideas, 2002.

9 http://bioethics.gov/

10 Fukuyama F. The great disruption. London: Profile Books, 1999.

11 Harris J. Clones, genes and immortality: ethics and the genetic revolution. Oxford: Oxford University Press, 1998.

12 Robertson J. Children of choice: freedom and the new reproductive technologies. Princeton, NJ: Princeton University Press, 1994.

13 Strathern $M$. Enterprising kinship: consumer choice and the new reproductive technologies. Reproducing the future: anthropology, kinship and the new reproductive technologies. Manchester: Manchester University Press, 1992.

14 See reference $4: 72-4$

15 Holm S. Genetic engineering and the North-South divide. In Dyson A Harris J, eds. Ethics and biotechnology. London: Routledge, 1994: 47-63.

16 Goodman B, ed. The philosophy of utopia. London: Frank Cass, 2001.

17 Brown N, Rappert B, Webster A, eds. Contested futures: a sociology of prospective technoscience. Aldershot: Ashgate, 2000.

18 Mannheim K. Ideology and utopia. London: Routledge, 1991.

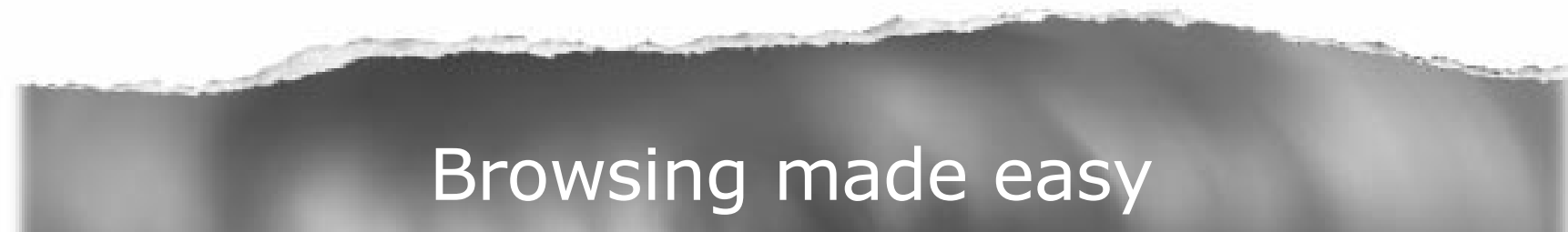

\section{Collections}

With a single click Collections allows you to find all articles that have been published in your chosen subject. Select from over 300 clinical and non-clinical topic collections and/or cross search other specialist journals, the BMJ and Cochrane Reviews

www.jmedethics.com 